\title{
Psoriasis and cardiometabolic disorders
}

\section{Łuszczyca i schorzenia kardiometaboliczne}

Julia Nowowiejska, Anna Baran, Iwona Flisiak

Department of Dermatology and Venereology, Medical University of Bialystok, Bialystok, Poland

Klinika Dermatologii i Wenerologii, Uniwersytet Medyczny w Białymstoku, Białystok, Polska

Dermatol Rev/Przegl Dermatol 2020, 107, 508-520

DOI: https://doi.org// 0.5 I | 4/dr.2020.103887

\section{CORRESPONDING AUTHOR/} ADRES DO KORESPONDENCJI: lek. Julia Nowowiejska

Klinika Dermatologii

i Wenerologii

Uniwersytet Medyczny

w Białymstoku

ul. Żurawia 14

15-540 Białystok, Polska

e-mail:

julia.nowowiejska@umb.edu.pl

\begin{abstract}
Psoriasis is a chronic, inflammatory, autoimmune skin disease affecting $2-4 \%$ of general population. It is an important social issue, because of its confirmed associations with metabolic syndrome. Individals with psoriasis are at an increased risk of developing cardiovascular disorders and diabetes mellitus. Psoriasis and its comorbidities have multiple common pathogenic pathways including the chronic inflammatory process, immunological abnormalities, genetic links and different bioactive proteins secreted by the adipose tissue. Considering the above associations, it is advisable to perform screening tests in patients with psoriasis to detect metabolic disorders as they not only increase mortality in these individuals, but also decrease their life quality significantly. An essential issue is also the education and the improvement of doctor-patient relationship, as well as early introducing of preventive measures.
\end{abstract}

\section{STRESZCZENIE}

Łuszczyca jest przewlekłą, zapalną, autoimmunologiczną chorobą skóry dotyczącą 2-4\% populacji. Stanowi istotny problem społeczny ze względu na związek z zespołem metabolicznym, co zwiększa ryzyko zachorowania na choroby układu sercowo-naczyniowego i cukrzycę. Łuszczyca i choroby z nią współistniejące mają wiele wspólnych szlaków patogenetycznych, m.in. przewlekły proces zapalny, zaburzenia immunologiczne, czynniki genetyczne oraz różne aktywne biologicznie substancje wydzielane przez tkankę tłuszczową. Ze względu na powyższe zależności celowe wydaje się wykonywanie u chorych na łuszczycę badań przesiewowych w kierunku zaburzeń kardiometabolicznych, gdyż nie tylko zwiększają one śmiertelność u tych chorych, lecz także znacznie obniżają jakość ich życia. Bardzo istotna jest też edukacja i poprawa relacji lekarz-pacjent oraz wczesne wdrażanie profilaktyki.

Key words: psoriasis, metabolic syndrome, obesity, diabetes mellitus, dyslipidemia.

Słowa kluczowe: łuszczyca, zespół metaboliczny, otyłość, cukrzyca, dyslipidemia. 


\section{INTRODUCTION}

Psoriasis is a chronic, inflammatory, autoimmune skin disease affecting $2-4 \%$ of the population, pathogenesis of which is complex and still being studied [1]. This dermatosis is a significant social problem, as it has been proven to be strongly related to the metabolic syndrome (MS), and therefore a greater risk of developing cardiovascular diseases (CVD), obesity and diabetes mellitus (DM) [2]. In this group of patients, depression and alcohol abuse are also observed more frequently [2]. Mortality in patients with psoriasis is significantly higher than in the general population, which is especially due to more frequent cardiovascular events [1, 2]. Psoriasis and cardiometabolic diseases (CMDs) share many pathogenic pathways, including the phenomenon of a metabolically induced chronic inflammatory process, immunological and lipid disorders, genetic factors and participation of various biologically active substances secreted by adipose tissue $[1,3]$.

On the basis of the current literature, the article presents selected issues concerning the pathophysiology of psoriasis and its relations with systemic diseases secondary to metabolic disorders. The multidirectional impact of psoriasis therapy on the above disorders and possibilities of preventing the development of comorbidity are also described.

\section{CARDIOMETABOLIC DISORDERS CO-EXISTING WITH PSORIASIS}

\section{Metabolic syndrome}

A diagnosis of MS can be made when a patient meets 3 of 5 criteria: 1 ) increased waist circumference (in the European population $\geq 80 \mathrm{~cm}$ in women and $\geq 94 \mathrm{~cm}$ in men), 2) triglyceride levels $>150 \mathrm{mg} / \mathrm{dl}$ or treatment of hypertriglyceridemia, 3) HDL-C levels $<40 \mathrm{mg} / \mathrm{dl}$ in men and $<50 \mathrm{mg} / \mathrm{dl}$ in women or treatment for this disorder, 4) systolic blood pressure $\geq 130 \mathrm{~mm} \mathrm{Hg}$ or diastolic blood pressure $\geq 85 \mathrm{~mm}$ $\mathrm{Hg}$, or treatment of previously diagnosed arterial hypertension, 5) fasting blood glucose $\geq 100 \mathrm{mg} / \mathrm{dl}$ or pharmacological treatment of type 2 diabetes [4, 5]. The key phenomenon is abdominal obesity, which is the starting point for other pathogenic MS pathways. This syndrome increases the risk of other cardiovascular diseases, both atherosclerotic and unrelated to atherosclerosis. In order to treat MS, not only pharmacological treatment should be undertaken, but also lifestyle should be changed [6]. There are many reports in the literature on a significant relationship between psoriasis and the metabolic syndrome, it is estimated that it affects $20-50 \%$ of patients. Moreover, the increase in the incidence of MS depends on

\section{WPROWADZENIE}

Łuszczyca jest obejmującą 2-4\% populacj przewlekłą, zapalną, autoimmunologiczną chorobą skóry o złożonej, będącej nadal przedmiotem badań patogenezie [1]. Dermatoza ta jest istotnym problemem społecznym, gdyż udowodniono jej silny związek z zespołem metabolicznym (metabolic syndrome - MS) i tym samym zwiększenie ryzyka zachorowania na choroby układu sercowo-naczyniowego (cardiovascular diseases - CVD), otyłość i cukrzycę (diabetes mellitus - DM) [2]. W grupie pacjentów $\mathrm{z}$ tą jednostką chorobową częściej obserwuje się także depresję oraz nadużywanie alkoholu [2]. Śmiertelność wśród chorych na łuszczycę jest istotnie wyższa niż w populacji ogólnej, co wynika z częstszych incydentów sercowo-naczyniowych [1, 2]. Łuszczyca i choroby kardiometaboliczne (cardiometabolic diseases - CMD) mają wiele wspólnych cech patogenetycznych, m.in. zjawisko metabolicznie wywołanego przewlekłego procesu zapalnego, zaburzenia immunologiczne, lipidowe, czynniki genetyczne oraz udział aktywnych biologicznie substancji wydzielanych przez tkankę tłuszczową [1, 3].

W artykule przedstawiono na podstawie aktualnego piśmiennictwa wybrane zagadnienia dotyczące patofizjologii łuszczycy oraz jej powiązań z chorobami ogólnoustrojowymi powstałymi na podłożu zaburzeń metabolicznych. Opisano również wielokierunkowy wpływ terapii łuszczycy na powyższe zaburzenia oraz możliwości zapobiegania współchorobowości.

\section{ZABURZENIA KARDIOMETABOLICZNE WSPÓŁISTNIEJACE Z ŁUSZCZYCA}

\section{Zespół metaboliczny}

Zespół metaboliczny można rozpoznać, gdy pacjent spełnia 3 z 5 kryteriów: 1) zwiększony obwód talii (w populacji europejskiej $\geq 80 \mathrm{~cm} \mathrm{u}$ kobiet $\mathrm{i} \geq 94 \mathrm{~cm}$ u mężczyzn), 2) stężenie trójglicerydów $>150 \mathrm{mg} / \mathrm{dl}$ lub leczenie hipertrójglicerydemii, 3) stężenie HDL-C < 40 mg/dl u mężczyzn i $<50 \mathrm{mg} / \mathrm{dl}$ $\mathrm{u}$ kobiet lub leczenie tego zaburzenia, 4) ciśnienie tętnicze skurczowe $\geq 130 \mathrm{~mm} \mathrm{Hg}$ lub rozkurczowe $\geq 85 \mathrm{~mm}$ $\mathrm{Hg}$ lub leczenie rozpoznanego wcześniej nadciśnienia tętniczego, 5) stężenie glukozy w osoczu na czczo $\geq 100$ $\mathrm{mg} / \mathrm{dl}$ lub leczenie farmakologiczne cukrzycy typu 2 $[4,5]$. Najważniejszy objaw to otyłość brzuszna, która jest początkowym punktem dla pozostałych ścieżek patogenetycznych MS. Zespół metaboliczny zwiększa ryzyko wystąpienia innych schorzeń sercowo-naczyniowych, zarówno takich, u których podłoża leży miażdżyca, jak i niezwiązanych z miażdżycą. W celu leczenia MS należy podejmować nie tylko postępowanie farmakologiczne, lecz także działania polegające 
severity of psoriasis [5, 7-9]. There are several genes associated with susceptibility to psoriasis (PSORS 1-3), which also predispose to the development of metabolic syndrome, type 2 diabetes, familial hyperlipidemia, and cardiovascular diseases [10].

\section{Obesity}

Obesity, and specifically abdominal (visceral) obesity, is the basic diagnostic criterion of metabolic syndrome $[4,10]$. There are numerous studies confirming a higher incidence of obesity in patients with psoriasis $[2,8,11]$. Such a relationship is observed especially in patients with a severe course of this disease, combined with a more frequent polymorphism of the FTO rs9930506 gene, which in turn is associated with a high body mass index (BMI) [12]. Psoriasis is subject to a network of interrelationships with obesity: obesity exacerbates psoriasis lesions, and conversely, psoriasis predisposes to obesity $[2,3,8]$. It was shown that the presence of the HLA Cw6 antigen in obese people increased the risk of psoriasis 35 times in relation to people of normal body weight, without this antigen [13]. It is estimated that the odds ratio of the coexistence of obesity and psoriasis is 1.66 compared to healthy people. In mild dermatosis it is 1.46 , in severe dermatosis 2.23 , which means that psoriasis itself increases the risk of obesity by over 50\% [14]. There are also reports in the literature about a linear correlation between BMI and the risk of psoriasis $[8,15]$. It was proven that obese people had a lower number and impaired function of circulating NK lymphocytes (natural killers) and a lower accumulation of their iNKT (invariant natural killers $\mathrm{T}$ cells) in the greater omentum, compared to people with normal body weight [16]. When stimulated, iNKT cells can produce pro-inflammatory cytokines that target the immune response to proliferation of Th1 or Th17 lymphocytes, or a Th2 mediated anti-inflammatory response [16]. They are iNKT cells that turn out to be important in pathogenesis of various diseases, including obesity, but also psoriasis [16]. Patients with psoriasis more often suffer from depressive disorders, isolate themselves from society, have inappropriate eating habits and limited physical activity, all of which are conducive to weight gain [8]. Systemic inflammation in psoriasis also contributes to exacerbation of inflammation in adipose tissue and vice versa. The coexistence of psoriasis and obesity leads to the development of insulin resistance and vascular endothelial dysfunction, and consequently to CVD, which is referred to as the psoriatic march [17]. Visceral obesity was shown to be associated with the subclinical stage of CVD, as measured by vasculitis, confirmed by ${ }^{18} \mathrm{~F}-\mathrm{FDG}$ PET/CT. At the same time, a loss of body weight and visceral fat reduces its intensity [18]. Adipose tissue is an important source na zmianie stylu życia [6]. W literaturze istnieje wiele doniesień na temat ścisłego związku między łuszczycą i MS. Szacuje się, że dotyczy on $20-50 \%$ pacjentów, ponadto obserwuje się zależność wzrostu częstości występowania MS od stopnia nasilenia łuszczycy [5, 7-9]. Istnieje kilka genów decydujących o zachorowaniu na łuszczycę (PSORS 1-3) oraz rozwoju MS, cukrzycy typu 2, hiperlipidemii rodzinnej, a także chorób układu krążenia [10].

\section{Otyłość}

Otyłość brzuszna (trzewna) stanowi podstawowe kryterium diagnostyczne MS [4, 10]. Istnieją liczne badania potwierdzające częstsze występowanie otyłości u pacjentów z łuszczycą $[2,8,11]$. Taką zależność obserwuje się zwłaszcza u osób z ciężkim przebiegiem tej choroby połączonym z częstszym występowaniem polimorfizmu genu FTO rs9930506, który związany jest z wysokim wskaźnikiem masy ciała (body mass index - BMI) [12]. Łuszczyca podlega sieci wzajemnych zależności z otyłością: otyłość nasila zmiany łuszczycowe i odwrotnie - łuszczyca predysponuje do otyłości [2, 3, 8]. Wykazano, że obecność antygenu HLA Cw6 wśród osób otyłych zwiększała ryzyko rozwoju łuszczycy 35 razy w stosunku do osób o prawidłowej masie ciała nieposiadających tego antygenu [13]. Szacuje się, że iloraz szans współistnienia otyłości i łuszczycy wynosi 1,66 w porównaniu z osobami zdrowymi. W łagodnej postaci tej dermatozy wynosi on 1,46 , w ciężkiej 2,23, co oznacza, że łuszczyca zwiększa ryzyko otyłości o ponad 50\% [14]. W piśmiennictwie można znaleźć także doniesienia o liniowej korelacji BMI z ryzykiem zachorowania na łuszczycę $[8,15]$. Dowiedziono, że osoby otyłe mają mniejszą liczbę oraz osłabioną funkcję krążących limfocytów NK (natural killers) oraz mniejszą akumulację ich podtypu iNKT (invariant natural killers T cells) w sieci większej w porównaniu z osobami z prawidłową masą ciała [16]. Komórki iNKT mogą po pobudzeniu wytwarzać cytokiny prozapalne ukierunkowujące odpowiedź immunologiczną na proliferację limfocytów Th1 lub Th17 lub odpowiedź przeciwzapalną z udziałem Th2 [16]. Komórki iNKT mają istotne znaczenie w patogenezie m.in. otyłości, ale także łuszczycy [16]. Chorzy na łuszczycę częściej mają zaburzenia depresyjne, izolują się od społeczeństwa, mają nieprawidłowe nawyki żywieniowe i ograniczoną aktywność fizyczną, a wszystkie te czynniki sprzyjają wzrostowi masy ciała [8]. Układowy proces zapalny w łuszczycy przyczynia się do nasilenia stanu zapalnego w tkance tłuszczowej i odwrotnie. Współwystępowanie łuszczycy i otyłości prowadzi do rozwoju insulinooporności i dysfunkcji śródbłonka naczyń, a w konsekwencji do CVD, co określane jest mianem marszu łuszczycowego [17]. Wykazano, że otyłość trzewna 
of adipokines that can cause metabolic disturbances or have a protective effect. These substances can also induce aggravation of psoriatic lesions. Levels of protective adipokines -adiponectin and omentin are usually lowered in patients with severe psoriasis, and at the same time higher concentrations of leptin, visfatin and resistin are observed, and their decrease with the disappearance of eruptions [19]. Apart from comorbidity, obesity contributes to lower effectiveness of psoriasis treatment and more frequent side effects of anti-psoriatic therapy [1].

\section{Arterial hypertension}

The meta-analysis of 24 observational studies showed a relationship between arterial hypertension and psoriasis at the level of $\mathrm{OR}=1.58$ [3]. Both diseases share common risk factors, incl. obesity and smoking. Moreover, the systemic inflammatory process present in psoriasis favors development of hypertension [20]. There are also common pathogenetic pathways in both these diseases: the phenomenon of oxidative stress, overexpression of endothelin in endothelial cells and keratinocytes, and participation of TNF- $a$ and IL-17 [21]. A higher incidence of hypertension in patients with psoriasis was confirmed. Hypertension increases with increasing severity of psoriasis [3, 22]. Additionally, more severe and less controlled arterial hypertension is observed in patients with psoriasis, which also progresses with the increasing severity of the dermatosis $[3,11]$. Causes of these relationships are not fully understood. It is suspected that they may be a result of increased activity of the angiotensin-converting enzyme (ACE), endothelin 1 and renin, concentrations of which increase in patients with psoriasis. Those enzymes demonstrate vasoconstrictive properties, leading to increased blood pressure [22].

\section{Diabetes mellitus}

Research shows that patients with psoriasis are significantly more likely to develop type 2 diabetes, although the exact basis of this relationship has not been fully understood so far [11, 23]. Genetic and metabolic conditions are postulated as two main factors linking these diseases. There are two genes that have been linked to both psoriasis and type 1 and 2 diabetes mellitus - PTPN22 and CDKAL1, respectively [5]. In terms of metabolic aspects, elevated levels of free fatty acids present in both psoriasis and MS cause adipocyte dysfunction and inhibition of insulin secretion, favoring development of type 2 diabetes [5]. Psoriasis is considered to be an independent risk factor for DM. The risk of DM increases with increasing severity of skin lesions [3,23]. It was proven that patients with psoriasis and diabetes more often jest powiązana z subklinicznym stadium CVD, czego miernikiem może być zapalenie naczyń potwierdzane metodą ${ }^{18} \mathrm{~F}-F D G$ PET/CT. Utrata masy ciała i trzewnej tkanki tłuszczowej zmniejsza jej nasilenie [18]. Tkanka tłuszczowa jest istotnym źródłem adipokin, które mogą powodować zaburzenia metaboliczne lub mieć działanie protekcyjne. Substancje te mogą również indukować nasilenie zmian łuszczycowych. Stężenia protekcyjnie działających adipokin - adiponektyny i omentyny - są zazwyczaj zmniejszone u pacjentów z ciężkim przebiegiem łuszczycy, a jednocześnie obserwuje się u nich większe stężenia leptyny, wisfatyny i rezystyny oraz ich zmniejszanie się wraz z ustępowaniem wykwitów [19]. Pomijając współchorobowość, otyłość przyczynia się do mniejszej skuteczności leczenia łuszczycy oraz częstszych działań niepożądanych terapii przeciwłuszczycowej [1].

\section{Nadciśnienie tętnicze}

Metaanaliza 24 badań obserwacyjnych wykazała związek nadciśnienia tętniczego z łuszczycą na poziomie $\mathrm{OR}=1,58$ [3]. Obie choroby mają wspólne czynniki ryzyka, m.in. otyłość i palenie papierosów. Ponadto obecny w łuszczycy ogólnoustrojowy proces zapalny sprzyja rozwojowi nadciśnienia [20]. Istnieją także wspólne szlaki patogenetyczne w obu tych chorobach: zjawisko stresu oksydacyjnego, nadekspresja endoteliny w komórkach śródbłonka i keratynocytach oraz udział TNF-a i IL-17 [21]. Potwierdzono większą częstość występowania nadciśnienia u chorych na łuszczycę, która wzrasta wraz z nasileniem ciężkości łuszczycy [3, 22]. Dodatkowo obserwuje się bardziej nasilone i gorzej kontrolowane nadciśnienie tętnicze wśród pacjentów z łuszczycą, co koreluje z nasileniem łuszczycy $[3,11]$. Przyczyna tych powiązań nie została dokładnie poznana. Podejrzewa się, że mogą one wynikać ze zwiększonej aktywności enzymu konwertującego angiotensynę (angiotensin-converting enzyme - ACE), endoteliny 1 oraz reniny, których stężenie u pacjentów z łuszczycą jest zwiększone, a które wykazują działanie wazokonstrykcyjne, podwyższając ciśnienie tętnicze krwi [22].

\section{Cukrzyca}

Badania dowodzą, że u chorych na łuszczycę istotnie częściej występuje cukrzyca typu 2, jednak podłoże tych związków nie zostało dotychczas w pełni poznane [11, 23]. Podejrzewa się uwarunkowania genetyczne oraz metaboliczne. Istnieją dwa geny, które zostały powiązane zarówno z łuszczycą, jak i cukrzycą typu 1 i 2 - odpowiednio PTPN22 i CDKAL1 [5]. W kwestii aspektów metabolicznych - zwiększone stężenie wolnych kwasów tłuszczowych, obecne zarówno w łuszczycy, jak i MS, zaburza funkcjonowanie adipocytów i hamowanie wydzielania insuliny, 
developed microvascular and macrovascular complications than people without this dermatosis, and these patients more often required pharmacological treatment of diabetes [3]. It is also postulated that hyperinsulinemia may provoke the spread of psoriatic lesions or worsen the condition of existing ones [24]. On the other hand, there are data on the positive effect of psoriasis therapy on blood glucose concentration. The glucose level decreases and contributes to the improvement of carbohydrate metabolism [25]. Similarly, improvement of psoriatic lesions was shown in patients treated for diabetes with PPAR $\gamma$ agonists, which are significant in the pathogenesis of psoriasis [26].

\section{Dyslipidemia}

Blood lipid disorders are one of the main risk factors for cardiovascular diseases, which can also be modified. Dyslipidemia usually does not cause immediate symptoms, and therefore screening tests are necessary to identify patients who require treatment. In treatment, apart from lifestyle modification, pharmacological agents are used, and when indicated, even surgical interventions [27, 28].

The relationship between psoriasis and dyslipidemia has been widely documented $[1,8,11,29]$. Patients with psoriasis have a more atherogenic serum lipid profile, i.e. higher levels of total cholesterol, low density lipoprotein (LDL) and triglycerides, as well as lower high density lipoprotein (HDL) levels [1, 3]. In turn, dyslipidemia may contribute to weight gain and obesity, which is more common in patients with psoriasis $[4,8,10]$. There are studies that postulate that chronic inflammation leads to structural changes of proteins and formation of new epitopes, which in turn induce autoantibody formation and changes in HDL. These antibodies can be seen as a kind of markers of cardiovascular risk in the group of patients with autoimmune diseases. These are, for example, antibodies to HDL and apolipoprotein A, that can be detected in serum of patients with psoriasis. It is even postulated that their presence correlates with severity of the disease and may contribute to formation of atherosclerotic plaque in these patients [30]. Despite the increased prevalence of lipid disorders in patients with psoriasis, the disease itself is not an indication for immediate initiation of serum lipid-lowering therapy. Commonly used guidelines for the treatment of dyslipidemia applicable to the general population also apply to people with psoriasis. On the other hand, statins, one of the most commonly used drugs in lipid disorders, were demonstrated to reduce severity of psoriatic lesions [30, 31].

\section{Atherosclerosis}

Atherosclerosis is an inflammatory disease based on both immunological phenomena and environmen- sprzyjając rozwojowi cukrzycy typu 2 [5]. Łuszczyca jest uważana za niezależny czynnik ryzyka zachorowania na cukrzycę, które wzrasta wraz z nasileniem zmian skórnych [3, 23]. Udowodniono, że u pacjentów z łuszczycą i cukrzycą częściej dochodzi do powikłań mikro- i makronaczyniowych w porównaniu z osobami bez tej dermatozy oraz chorzy ci częściej wymagają leczenia farmakologicznego cukrzycy [3]. Przypuszcza się, że hiperinsulinemia może prowokować wysiew zmian łuszczycowych lub pogarszać stan już istniejących wykwitów [24]. Istnieją dane o pozytywnym wpływie terapii łuszczycy na stężenie glukozy we krwi. Ulega ono zmniejszeniu, co przyczynia się do poprawy gospodarki węglowodanowej [25]. Podobnie wykazano poprawę w zakresie zmian łuszczycowych u pacjentów leczonych z powodu cukrzycy agonistami receptorów PPAR $\gamma$, które są istotne w patogenezie łuszczycy [26].

\section{Dyslipidemia}

Zaburzenia lipidowe są jednym z głównych czynników ryzyka chorób sercowo-naczyniowych, a jednocześnie są czynnikiem modyfikowalnym. Dyslipidemia zazwyczaj nie powoduje bezpośrednich objawów chorobowych, dlatego niezbędne są badania przesiewowe, by wyodrębnić chorych wymagających leczenia. W terapii oprócz modyfikacji stylu życia stosuje się środki farmakologiczne, a przy istnieniu wskazań nawet interwencje chirurgiczne [27, 28].

Związek łuszczycy z dyslipidemią został silnie udokumentowany $[1,8,11,29]$. U pacjentów z łuszczycą obserwuje się w surowicy typowo aterogenny profil lipidowy, tj. zwiększone stężenie cholesterolu całkowitego, cholesterolu frakcji LDL (low density lipoprotein) i trójglicerydów oraz zmniejszone stężenie cholesterolu frakcji HDL (high density lipoprotein) [1,3]. Dyslipidemia może się przyczyniać do wzrostu masy ciała i otyłości, co częściej dotyczy pacjentów z łuszczycą $[4,8,10]$. Istnieją badania sugerujące, że przewlekły stan zapalny prowadzi do zmian strukturalnych białek i powstawania nowych epitopów, a to $\mathrm{z}$ kolei indukuje powstawanie autoprzeciwciał i zmiany w HDL. Przeciwciała te mogą być traktowane jako swego rodzaju markery ryzyka sercowo-naczyniowego $\mathrm{w}$ grupie pacjentów z chorobami autoimmunologicznymi. Są to np. przeciwciała przeciwko HDL i apolipoproteinie A, które można wykryć w surowicy chorych na łuszczycę. Zauważono, że ich obecność koreluje ze stopniem nasilenia choroby i może się przyczyniać do powstawania blaszek miażdżycowych [30]. Pomimo zwiększonej częstości występowania zaburzeń lipidowych u pacjentów z łuszczycą, choroba nie jest wskazaniem do natychmiastowego włączania terapii zmniejszającej stężenie lipidów w surowicy. Powszechnie stosowane wytyczne leczenia dyslipidemii, które mają zasto- 
tal factors, which together lead to an increased cardiovascular risk [25].

Psoriasis is a recognized risk factor for development of atherosclerosis and CVD [18]. Psoriasis and atherosclerosis have a similar pathomechanism, as well as elements of histopathological presentation, e.g. migration of T lymphocytes and monocytes outside blood vessels [32, 33]. Inflammation is a key phenomenon in the development of atherosclerosis, similarly to psoriasis $[1,18]$. A similar profile of inflammatory cells and pro-inflammatory cytokines released by them is involved in formation of atherosclerotic plaque and of psoriatic lesions; similar immunological phenomena are also observed [25]. This systemic process, further aggravated by pro-inflammatory cytokines and adipokines produced by visceral adipose tissue, leads to development of insulin resistance and damage to endothelial cells. Endothelial dysfunction predisposes to formation of atherosclerotic plaques and, consequently, to CVD [17]. Endothelin plays an important role in both psoriasis and atherosclerosis. It is produced in excess by endothelial cells of blood vessels and inflammation-stimulated keratinocytes. Increased production of endothelin leads to an increase in blood pressure, which promotes development of atherosclerosis. Studies reported that the concentration of endothelin-1 in patients with psoriasis was increased, both in blood serum and in the affected skin, and correlated with the severity of skin lesions [25]. In patients with psoriasis, arterial wall stiffness increases, which additionally confirms that the state of systemic inflammation observed in psoriasis contributes to a more rapid development of atherosclerosis [34].

\section{Non-alcoholic fatty liver disease}

Numerous studies showed that patients with psoriasis had a 1.5- to 3-fold increased risk of non-alcoholic fatty liver disease (NAFLD), and even of a more severe liver fibrosis [35]. Both psoriasis and NAFLD are closely related to the metabolic syndrome [35]. Both diseases share numerous pathophysiological pathways, which additionally overlap with metabolic disorders present in both diseases. Excessively developed adipose tissue produces numerous bioactive substances, pro-inflammatory adipokines and non-esterified fatty acids, which are excessively absorbed by the liver and lead to its damage [36]. Intrahepatic oxidative stress is stimulated, as well as pro-atherogenic and inflammatory factors, which in turn play a significant role in pathophysiology of psoriasis. A more severe course of psoriasis and NAFLD is observed in the case of their coexistence, and the risk of long-term complications is more likely, as patients with psoriasis and NAFLD have higher levels of aminotransferases and higher values of non-inva- sowanie w populacji ogólnej, dotyczą również osób z łuszczycą. Jednocześnie udowodniono, że statyny, jedne $\mathrm{z}$ najczęściej stosowanych leków w zaburzeniach lipidowych, wpływają na zmniejszenie nasilenia zmian łuszczycowych $[30,31]$.

\section{Miażdżyca}

Miażdżyca jest chorobą o zapalnej patogenezie, u której podłoża leżą zjawiska immunologiczne, a także czynniki środowiskowe zwiększające ryzyko sercowo-naczyniowe [25].

Łuszczyca należy do czynników zwiększających ryzyko rozwoju miażdżycy i CVD [18]. Łuszczyca i miażdżyca mają zbliżony patomechanizm, oraz elementy obrazu histopatologicznego, m.in. migrację limfocytów T i monocytów poza naczynia krwionośne $[32,33]$. Kluczowym zjawiskiem w rozwoju miażdżycy podobnie jak w łuszczycy, jest stan zapalny $[1,18]$. W tworzeniu blaszki miażdżycowej bierze udział podobny profil komórek zapalnych i uwalnianych przez nie prozapalnych cytokin, jak w przypadku zmian łuszczycowych. Obserwowane są także zbliżone zjawiska immunologiczne [25]. Ten proces o wymiarze ogólnoustrojowym, dodatkowo potęgowany przez cytokiny prozapalne i adipokiny wytwarzane przez tkankę tłuszczową trzewną, prowadzi do rozwoju insulinooporności i uszkodzenia komórek śródbłonka. Zaburzenie jego funkcji predysponuje do powstawania blaszek miażdżycowych i w konsekwencji CVD [17]. Zarówno w łuszczycy, jak i miażdżycy istotną rolę odgrywa endotelina, która wytwarzana jest w nadmiarze przez komórki śródbłonka naczyń krwionośnych oraz stymulowane stanem zapalnym keratynocyty. Zwiększona produkcja endoteliny powoduje wzrost ciśnienia tętniczego krwi, co sprzyja rozwojowi miażdżycy. Z badań wynika, że stężenie endoteliny-1 u pacjentów z łuszczycą jest zwiększone zarówno w surowicy krwi, jak i w skórze zmienionej chorobowo oraz wykazuje korelację z ciężkością zmian skórnych [25]. U pacjentów z łuszczycą dochodzi do zwiększenia sztywności ścian naczyń tętniczych, co dodatkowo potwierdza, że stan układowego zapalenia w łuszczycy przyczynia się do szybszego rozwoju miażdżycy [34].

\section{Niealkoholowe stłuszczenie wątroby}

Liczne badania dowodzą, że łuszczyca zwiększa 1,5-3-krotnie ryzyko zachorowania na niealkoholowe stłuszczenie wątroby (non-alcoholic fatty liver disease - NAFLD), a nawet zwłóknienia wątroby [35]. Zarówno łuszczyca, jak i NAFLD są ściśle powiązane z MS [35]. Oba schorzenia posiadają wspólne szlaki patofizjologiczne, które dodatkowo nakładają się na zaburzenia metaboliczne obecne w obu chorobach. Nadmiernie rozwinięta tkanka 
sive liver fibrosis, compared to patients with NAFLD without psoriasis [37].

\section{DRUGS USED IN THE THERAPY OF PSORIASIS AND CARDIOMETABOLIC DISORDERS}

Various methods are used in the treatment of psoriasis, depending on type and severity of skin lesions, as well as the age, general condition and coexisting diseases of the patient. Their introduction must always take into account possible side effects - particularly in case of systemic treatment - and comorbidity. Many of them can exacerbate symptoms of pre-existing components of the metabolic syndrome. Popular drugs for systemic use, usually started in cases of moderate to severe psoriasis, are: acitretin, cyclosporine and methotrexate (MTX) [38]. Acitretin, a derivative of the second-generation retinoids, influences proliferation and differentiation of keratinocytes [39]. Apart from the recognized teratogenic effect and causing hypervitaminosis $\mathrm{A}$, it is important to remember about its influence on lipid metabolism, as it promotes hyperlipidemia, which according to some studies is observed in as many as $25-50 \%$ of patients $[4,10,38,39]$. Another adverse effect of acitretin is hepatotoxicity, which may only manifest itself as an increase in liver enzymes, but it may also progress to fibrosis and cirrhosis, similar to various stages of NAFLD $[38,39]$.

Another classic oral drug in the treatment of psoriasis is cyclosporine, usually intended for short-term treatment [38]. This drug may also aggravate symptoms of MS, as its adverse effects include increased blood pressure, hyperlipidemia and hyperglycemia $[4,38]$. It may also cause hyperuricemia, which, although it is not a criterion of MS, is closely related to the syndrome $[4,38]$. Moreover, it was shown that obese patients with psoriasis treated with cyclosporine A were at higher risk of nephrotoxicity. Therefore, it is recommended to determine the drug dose according to the patient's ideal body weight, rather than the current one. In turn, weight loss in patients with psoriasis improves the effectiveness of therapy with this drug [1]. Ahlehoff et al., in a 5-year follow-up of 6902 patients with psoriasis, showed no beneficial effect on reduction of cardiovascular risk either for cyclosporine $(\mathrm{HR}=1.06)$ or for acitretin $(\mathrm{HR}=1.8)[40]$.

Another classic anti-psoriatic drug is methotrexate, a folic acid antagonist that is known to be hepatotoxic. Most often the adverse reaction manifests itself, as in the case of acitretin, only with an increase in the activity of liver enzymes, but the use of the drug may also lead to cirrhosis [38]. Additionally, concomitant obesity may increase hepatotoxicity of the drug. At the same time, unlike acitretin and cyclosporine, tłuszczowa wytwarza liczne substancje bioaktywne, prozapalne adipokiny i nieestryfikowane kwasy tłuszczowe, które są w nadmiarze wychwytywane przez wątrobę i prowadzą do jej uszkodzenia [36]. Dochodzi do pobudzenia wewnątrzwątrobowego stresu oksydacyjnego oraz czynników proaterogennych i zapalnych, które są istotne $\mathrm{w}$ patofizjologii łuszczycy. Obserwuje się cięższy przebieg łuszczycy i NAFLD w przypadku ich współwystępowania oraz większe prawdopodobieństwo odległych powikłań. U pacjentów z łuszczycą i NAFLD odnotowuje się wyższą aktywność aminotransferaz oraz większe wartości nieinwazyjnych wskaźników włóknienia wątroby w porównaniu z pacjentami z NAFLD bez łuszczycy [37].

\section{LEKI STOSOWANE W TERAPII ŁUSZCZYCY A ZABURZENIA KARDIOMETABOLICZNE}

W terapii łuszczycy stosowane są zróżnicowane metody leczenia zależnie od rodzaju i nasilenia zmian skórnych, jak również wieku i stanu ogólnego pacjenta oraz schorzeń wspótistniejących. Zawsze należy wziąć pod uwagę możliwe działania niepożądane leczenia, zwłaszcza w przypadku leczenia ogólnego, oraz istniejcą współchorobowość. Wiele leków może nasilać objawy składowych MS. Powszechnie stosowanymi lekami w leczeniu ogólnym łuszczycy o nasileniu od umiarkowanego do ciężkiego są acytretyna, cyklosporyna i metotreksat (MTX) [38]. Acytretyna, pochodna retinoidów II generacji, wpływa na proliferacje i różnicowanie keratynocytów [39]. Oprócz działania teratogennego i powodowania hiperwitaminozy A, sprzyja występowaniu hiperlipidemii, która według niektórych badań jest obserwowana nawet u 25-50\% chorych $[4,10,38,39]$. Innym działaniem niepożądanym acytretyny jest hepatotoksyczność, która może się objawiać wzrostem aktywności enzymów wątrobowych, ale mozliwe jest wystąpienie do zwłóknienia i marskości, podobnie jak $w$ przypadku różnych stadiów NAFLD [38, 39].

Innym klasycznym doustnym lekiem wykorzystywanym w terapii łuszczycy jest cyklosporyna, przewidziana zwykle do krótkotrwałego leczenia [38]. Cyklosporyna może nasilać objawy MS, z powodu objawów niepożądanych: wzrostu ciśnienia tętniczego, hiperlipidemii i hiperglikemii $[4,38]$. Może także powodować hiperurykemię, która nie stanowi kryterium MS, ale jest $\mathrm{z}$ nim ściśle związana $[4,38]$. Ponadto wykazano, że u osób z otyłością i łuszczycą leczonych cyklosporyną występuje większe ryzyko nefrotoksyczności. $Z$ tego powodu zaleca się ustalanie dawki według idealnej, a nie aktualnej masy ciała chorego. Natomiast utrata masy ciała u pacjentów z łuszczycą wpływa na poprawę skuteczności terapii tym lekiem [1]. Ahlehoff i wsp. w 5-letniej obserwacji 
there are numerous data emphasizing the beneficial effect of MTX on reduction of cardiovascular risk $(\mathrm{HR}=0.53)[40]$. Biologic drugs are also used to treat moderate to severe psoriasis. These substances often have a two-way effect: they can increase the blood level of triglycerides, increase synthesis of leptin, as well as increase appetite and body weight [1]. Adalimumab increases the activity of liver enzymes in the blood serum [41]. At the same time, some biological drugs lead to an increase in HDL concentration in blood and a decrease in insulin concentration. There are also reports of their cardioprotective effect and lowering the risk of metabolic diseases [1]. Ahlehoff et al. confirmed that biological drugs lower the cardiovascular risk $(\mathrm{HR}=0.58)$ in patients with psoriasis, comparable, but not as significantly as methotrexate [40]. It was reported that adalimumab inhibited proliferation of vascular endothelial cells, reduced dimensions of blood vessels and size of the vascular network. More importantly, the use of the drug correlates with a reduction in the degree of keratinocyte proliferation, and thus with a reduction in severity of psoriatic lesions [42]. Taking into account common elements of psoriasis and CVD pathogenesis, particularly participation of IL-17, it can be assumed that a beneficial effect on reducing cardiovascular risk will be obtained by introducing other biological drugs in the treatment of psoriasis - secukinumab and ixekizumab - antibodies against IL-17A, and brodalumab - an antibody that binds to the IL-17 receptor [33, 43]. On the other hand, Ahlehoff et al. did not demonstrate any cardioprotective effect of ustekinumab $(\mathrm{HR}=1.52)[40]$. Perhaps, taking into account the data on the cardioprotective effect of selected drugs in psoriasis, their early introduction to treatment may be beneficial to reduce the incidence of CVD, and thus increase survival.

\section{CAN WE PREVENT?}

The clear relationship between psoriasis and cardiometabolic diseases implies the need to treat not only this dermatosis alone, but also its comorbidities. As mentioned above, a certain complication is the fact that some drugs successfully used in the treatment of psoriasis additionally exacerbate components of MS. Moreover, some drugs used in cardiology, including those positively influencing CMDs, such as $\beta$-blockers or ACE inhibitors, may exacerbate psoriatic lesions [44].

According to the consensus of the Polish Dermatological Society regarding the treatment of psoriasis, the primary task of a physician treating people with psoriasis is periodic determination of parameters in peripheral blood, informing about the functions of organs that may potentially be damaged in the course
6902 chorych na łuszczycę nie wykazali korzystnego wpływu cyklosporyny $(\mathrm{HR}=1,06)$ i acytretyny $(\mathrm{HR}=1,8)$ na obniżanie ryzyka sercowo-naczyniowego [40].

Kolejnym klasycznym lekiem przeciwłuszczycowym jest MTX, antagonista kwasu foliowego, który ma potwierdzone działanie hepatotoksyczne. Najczęściej objawia się to, podobnie jak w przypadku acytretyny, jedynie wzrostem aktywności enzymów wątrobowych, ale jego stosowanie może także prowadzić do marskości wątroby [38]. Hepatotoksyczność MTX może nasilać współistniejąca otyłość. Jednocześnie, w przeciwieństwie do acytretyny i cyklosporyny, istnieją liczne dane podkreślające korzystny wpływ MTX na redukcję ryzyka sercowo-naczyniowego $(\mathrm{HR}=0,53)[40]$. W leczeniu zmian łuszczycowych o nasileniu od umiarkowanego do ciężkiego stosowane są leki biologiczne. Substancje te mają często dwukierunkowe działanie: mogą powodować wzrost stężenia trójglicerydów we krwi, nasilać syntezę leptyny oraz zwiększać łaknienie i masę ciała [1]. Adalimumab powoduje wzrost aktywności enzymów wątrobowych w surowicy krwi [41]. Niektóre leki biologiczne powodują jednak zwiększenie stężenia HDL we krwi oraz zmniejszenie stężenia insuliny. Są także doniesienia o ich działaniu kardioprotekcyjnym i obniżającym ryzyko wystąpienia chorób metabolicznych [1]. Ahlehoff i wsp. potwierdzili, że leki biologiczne podobnie jak MTX, ale w mniejszym stopniu, obniżają ryzyko sercowo-naczyniowe $(\mathrm{HR}=0,58)$ u pacjentów z łuszczycą [40]. Istnieją doniesienia, że adalimumab hamuje proliferację komórek śródbłonka naczyniowego, zmniejsza wymiary naczyń krwionośnych i rozmiar sieci naczyniowej. Szczególnie istotne jest, że koreluje to ze zmniejszeniem stopnia proliferacji keratynocytów, a tym samym zmniejszeniem nasilenia zmian łuszczycowych [42]. Z powodu wspólnych elementów patogenezy łuszczycy i CVD, zwłaszcza udział IL-17, można przypuszczać, że korzystny wpływ na zmniejszenie ryzyka sercowo-naczyniowego będzie miało włączenie do leczenia łuszczycy innych leków biologicznych: sekukinumabu i iksekizumabu - przeciwciał przeciw IL-17A, oraz brodalumabu - przeciwciała wiążącego się z receptorem dla IL-17 $[33,43]$. Ahlehoff i wsp. nie wykazali kardioprotekcyjnego działania ustekinumabu (HR $=1,52$ ) [40]. Dane o kardioprotekcyjnym działaniu wybranych leków w łuszczycy wskazują, że wczesne wprowadzenie ich do leczenia może się przyczynić do zmniejszenia zachorowalności na CVD, a tym samym zwiększenia przeżywalności.

\section{CZY MOŻEMY ZAPOBIEGAĆ?}

Związek łuszczycy ze schorzeniami kardiometabolicznymi implikuje konieczność leczenia nie tylko 
of psoriasis therapy [38]. This also offers a simple method of preventing complications. However, there are no precise recommendations on prevention or treatment of specific comorbidities of psoriasis, which should often lead to more frequent screening than in the general population.

Obesity that coexists with psoriasis may reduce effectiveness of topical and systemic treatment of psoriasis as well as increase adverse effects of methotrexate and cyclosporin [45]. Studies reported that patients with psoriasis consumed more caloric meals and more simple sugars, and improper eating habits correlated with obesity, a more severe course of psoriasis and reduction in quality of life [46, 47]. At the same time, a low-calorie diet and weight reduction, also achieved by bariatric surgery, significantly improved condition of the skin and reduced concentration of circulating pro-inflammatory cytokines [45, 46]. Hence, maintaining an appropriate body weight is so crucial - not only due to negative systemic effects, but also intensification of psoriasis lesions. Apart from diet, regular physical activity is also important, as it supports the process of weight loss. Studies of patients with psoriasis report beneficial effect of weight loss on skin condition [48]. Rucević et al. showed that after 4 weeks of using a low-caloric diet, 82 patients with psoriasis showed a significant reduction in blood lipid parameters compared to the control group, as well as a significant reduction in severity of psoriasis [49]. Similar observations were made by Naldi et al. after a 20 -week diet and exercise regimen in 303 patients with psoriasis [46]. It should be emphasized that physical activity and diet are basic therapeutic methods, the easiest to implement in order to reduce the risk of CMDs [48]. Similarly, in case of dyslipidemia, it seems advisable, first of all, to implement an appropriate diet and physical activity in order to reduce body weight [39]. When the above interventions are insufficient, the addition of a statin (possibly in combination with ezetimibe) should be considered in the case of predominance of hypercholesterolemic disorders, or fibrate - in case of predominance of hypertriglyceridemia $[39,50]$. Patients with psoriasis taking simvastatin show a significant decrease in total cholesterol, LDL fraction and triglycerides, as well as a faster and more effective decrease in intensity of changes in the PASI scale [31]. In patients at a very high cardiovascular risk, when the target LDL concentration is not achieved despite the use of a statin at the maximum tolerated dose in combination with ezetimibe, other preparations PCSK9 inhibitors (evolocumab, alirocumab) should also be considered [50]. The mechanism of action of these drugs is to inhibit PCSK9 (proprotein convertase subtilisin/kexin type-9), a protein that leads to down regulation of the number of receptors for LDL, tej dermatozy, lecz także chorób współistniejących. Jak wspomniano powyżej, pewnym utrudnieniem jest fakt, że niektóre leki z powodzeniem stosowane w terapii łuszczycy nasilają komponenty MS. Ponadto niektóre leki wykorzystywane w kardiologii, także te pozytywnie wpływające na choroby kardiometaboliczne:, $\beta$-adrenolityki i inhibitory ACE, mogą powodować nasilenie zmian łuszczycowych [44].

W rekomendacjach Polskiego Towarzystwa Dermatologicznego dotyczących łuszczycy zaleca się okresowe oznaczanie we krwi obwodowej parametrów funkcji narządów, które mogą ulec uszkodzeniu w przebiegu terapii łuszczycy [38]. Zwraca jednak uwagę, że rekomendacje te nie odnoszą się do szczegółowych zasad postępowania w zakresie profilaktyki i leczenia chorób towarzyszących łuszczycy.

Współistniejąca otyłość może zmniejszać skuteczność leczenia miejscowego i ogólnego łuszczycy oraz nasilać działania niepożądane MTX i cyklosporyny [45]. Badania donoszą, że pacjenci z łuszczycą spożywają kaloryczne posiłki i dużo cukrów prostych, a nieprawidłowe nawyki żywieniowe korelują z występowaniem otyłości, cięższym przebiegiem łuszczycy i obniżeniem jakości życia [46, 47]. Jednocześnie niskokaloryczna dieta i redukcja masy ciała, również dzięki operacjom bariatrycznym, przynosi znaczną poprawę stanu skóry oraz obniża stężenia krążących cytokin prozapalnych $[45,46]$. Z tego powodu podstawowe znaczenie ma utrzymywanie odpowiedniej masy ciała - nie tylko ze względu na negatywne skutki ogólnoustrojowe, lecz także na nasilenie zmian łuszczycowych. Poza stosowaniem diety ważna jest regularna aktywność fizyczna, która wspomaga proces redukcji masy ciała, a badania przeprowadzone wśród pacjentów z łuszczycą donoszą o jej korzystnym wpływie na stan skóry [48]. Rucević i wsp. wykazali, że po 4 tygodniach stosowania niskokalorycznej diety u 82 chorych z łuszczycą nastąpiła znamienna poprawa parametrów lipidowych w porównaniu z grupą kontrolną, jak również istotne zmniejszenie nasilenia zmian łuszczycowych [49]. Podobne obserwacje poczynili Naldi i wsp. po 20-tygodniowym reżimie dietetycznym i zwiększonym wysiłku fizycznym u 303 pacjentów z łuszczycą [46]. Należy podkreślić, że aktywność fizyczna i dieta to podstawowe metody terapeutyczne, najprostsze do wdrożenia w celu redukcji ryzyka CMD [48]. W przypadku dyslipidemii również celowe wydaje się przede wszystkim zastosowanie odpowiedniej diety i aktywności fizycznej w celu redukcji masy ciała [39]. Jeżeli jest to niewystarczające, należy rozważyć włączenie do leczenia (ewentualnie $\mathrm{w}$ połączeniu z ezetymibem) w przypadku przewagi zaburzeń o charakterze hipercholesterolemii lub fibratu w przypadku przewagi hipertrójglicerydemii $[39,50]$. U pacjentów z łuszczycą przyjmujących 
which in turn results in increased blood LDL level [51]. The relationship of PCSK9 with psoriasis was proven, as this protein was highly expressed in psoriatic lesions and seemed to favor development of cardiometabolic complications in these patients [51]. However, in-depth research is necessary in order to establish unambiguous recommendations regarding the use of these common drugs in prevention of psoriasis comorbidity.

In patients with diagnosed MS or psoriasis, the probability of carbohydrate metabolism disorders should always be taken into account [11, 23]. There are reports that etancercept may have a positive effect on the reduction of glycaemia in patients with psoriasis [52]. Oral antidiabetic drugs from the group of PPARY agonists (glitazones) and metformin may improve condition of the skin in patients [26]. Patients with psoriasis are at significantly increased overall cardiovascular risk [46]. It has been shown that after considering this dermatosis according to the Framingham scale, as many as $60 \%$ of patients with psoriasis were reclassified to higher risk categories [53]. This emphasizes the need for regular evaluation of people with psoriasis for cardiometabolic conditions and appropriate control of already diagnosed conditions.

It is worth quoting the joint guidelines of the American Academy of Dermatology and the National Psoriasis Foundation (USA) published in 2019, which emphasize that every patient with psoriasis should be screened for, among others, arterial hypertension hyperlipidemia and diabetes mellitus according to national recommendations [54]. In addition, physicians should consider initiating and more frequent screening for CVD risk factors for individuals with skin lesions $>10 \%$ of the body surface area, as well as candidates for general therapy or phototherapy [54].

American experts emphasized the importance of patient education in the field of etiology, comorbidities, treatment options and modification of lifestyle factors. They also indicated the need for joint decision making and improvement of the doctor-patient relationship, which would increase patient's satisfaction level and likelihood of their compliance with medical recommendations and reduce the risk of comorbidity [54]. Importantly, the guidelines emphasized the need to broaden the knowledge of comorbidities of psoriasis also among physicians, including dermatologists [54]. Unfortunately, studies report that awareness of the comorbidity of psoriasis is low, and it is dermatologists who are often the first physicians who can and should continue to refer their patients to their family doctor and appropriate specialists, and thus enable simple screening tests, as well as recommend modification lifestyle and provide information on risk factors for the disease [54-57]. simwastatynę obserwuje się znamienne zmniejszenie stężenia cholesterolu całkowitego, frakcji LDL i trójglicerydów, jak również szybszy i bardziej efektywny spadek nasilenia zmian w skali PASI [31]. U osób z bardzo dużym ryzkiem sercowo-naczyniowym, gdy nie osiągnięto docelowego stężenia LDL pomimo stosowania statyny w maksymalnej tolerowanej dawce w połączeniu z ezetymibem, należy rozważyć także inne preparaty - inhibitory PCSK9 (ewolokumab, alirokumab) [50]. Mechanizm działania tych leków polega na hamowaniu PCSK9 (konwertaza białkowa subtylizyny/keksyny typu 9, proprotein convertase subtilisin/kexin type-9), białka, które prowadzi do ujemnej regulacji liczby receptorów dla LDL, co skutkuje zwiększeniem stężenia LDL we krwi [51]. Udowodniono także związek PCSK9 z łuszczycą, gdyż białko to wykazuje wzmożoną ekspresję w zmianach łuszczycowych oraz może sprzyjać rozwojowi powikłań kardiometaboliczych u [51]. Niezbędne jest jednak pogłębienie badań w celu ustalenia jednoznacznych zaleceń odnośnie do zastosowania tych leków w profilaktyce współchorobowości łuszczycy.

U pacjentów z rozpoznanym MS lub łuszczycą powinno się zawsze brać pod uwagę duże prawdopodobieństwo wystąpienia zaburzenia gospodarki węglowodanowej [11, 23]. Są doniesienia, że etancercept może mieć wpływ na redukcję glikemii u chorych na łuszczycę [52]. Doustne leki przeciwcukrzycowe z grupy agonistów PPARY (glitazony) oraz metformina mogą powodować poprawę stanu skóry [26]. Chorzy na łuszczycę mają znamiennie zwiększone ogólne ryzyko sercowo-naczyniowe [46]. Wykazano, że po uwzględnieniu tej dermatozy w skali Framingham aż $60 \%$ chorych na łuszczycę zostało zaklasyfikowanych do wyższych kategorii ryzyka [53]. Podkreśla to konieczność regularnej oceny osób z łuszczycą pod kątem schorzeń kardiometabolicznych oraz odpowiedniej kontroli już rozpoznanych schorzeń.

Warto przytoczyć opublikowane w 2019 r. wspólne wytyczne Amerykańskiej Akademii Dermatologii i Narodowej Fundacji Łuszczycy (USA), które podkreślają, że każdy pacjent z łuszczycą powinien być poddawany badaniom przesiewowym w kierunku m.in. nadciśnienia tętniczego, hiperlipidemii i cukrzycy według zaleceń krajowych [54]. Ponadto u osób ze zmianami zajmującymi > 10\% powierzchni skóry, jak również kandydatów do leczenia ogólnego lub fototerapii lekarze powinni rozważyć wcześniejsze rozpoczęcie i częstsze wykonywanie badań przesiewowych w kierunku czynników ryzyka CVD [54].

Eksperci amerykańscy podkreślili znaczenie edukacji pacjentów w zakresie etiologii, chorób współistniejących, możliwości leczenia i modyfikacji czynników związanych ze stylem życia. Wskazali również potrzebę wspólnego podejmowania decyzji i poprawy relacji lekarz-pacjent, co zwiększy poziom satys- 


\section{CONCLUSIONS}

Psoriasis as a systemic disease is associated with cardiometabolic disorders by many shared pathogenetic pathways. It is necessary not only to properly treat psoriasis, but also to take a holistic approach to the patient and their disease as a disease affecting not only the skin, but the whole organism. Therefore, it is advisable to screen patients with psoriasis for comorbidities, perhaps even more often than subjects in the general population. And then the interdisciplinary cooperation of doctors of many specialties and treatment of other diagnosed disorders is advisable. It is extremely important to educate patients and improve the doctor-patient relationship, as well as implement prophylaxis as early as possible, as it seems to be the most important factor in preventing comorbidity.

\section{CONFLICT OF INTEREST}

The authors declare no conflict of interest. fakcji chorych oraz prawdopodobieństwo stosowania się przez nich do zaleceń lekarskich, a także zmniejszy ryzyko współchorobowości [54]. Co ważne, w wytycznych podkreślono konieczność pogłębienia wiedzy z zakresu chorób współistniejących z łuszczycą również wśród lekarzy, w tym dermatologów [54]. Badania wskazują, że świadomość współchorobowości łuszczycy jest niska, a to właśnie dermatolodzy są często pierwszymi lekarzami, którzy mogą kierować swoich pacjentów w celu przeprowadzenia testów przesiewowych, jak również zalecać modyfikację stylu życia i informować o czynnikach ryzyka wystąpienia chorób [54-57].

\section{WNIOSKI}

Łuszczyca jako schorzenie ogólnoustrojowe jest powiązana wieloma wspólnymi szlakami patogenetycznymi z zaburzeniami kardiometabolicznymi. Konieczne jest nie tylko właściwe leczenie łuszczycy, ale podejście holistyczne do pacjenta i jego choroby jako schorzenia dotyczącego nie tylko skóry, ale całego organizmu. Wskazane są badania przesiewowe pacjentów z łuszczycą w kierunku chorób współistniejących, interdyscyplinarna współpraca lekarzy wielu specjalności oraz terapia innych zdiagnozowanych zaburzeń. Niezwykle ważna jest edukacja chorych i poprawa relacji między lekarzem a pacjentem oraz wczesne wdrażanie profilaktyki, która wydaje się najważniejszym czynnikiem zapobiegającym współchorobowości.

\section{KONFLIKT INTERESÓW}

Autorzy nie zgłaszają konfliktu interesów.

\section{References}

\section{Piśmiennictwo}

1. Baran A., Kiluk P., Myśliwiec H., Flisiak I.: The role of lipids in psoriasis. Przegl Dermatol 2017, 104, 619-635.

2. Ryan C., Kirby B.: Psoriasis is a systemic disease with multiple cardiovascular and metabolic comorbidities. Dermatol Clin 2015, 33, 41-55.

3. Takeshita J., Grewal S., Langan S.M., Mehta N.N., Ogdie A., Van Voorhees A.S., et al.: Psoriasis and comorbid diseases: Epidemiology. J Am Acad Dermatol. 2017, 76, 377-390.

4. Sieradzki J., Płaczkiewicz-Jankowska E.: Zespół metaboliczny. [w:] Interna Szczeklika 2017. B. Jarząb (eds.). Medycyna Praktyczna, Kraków, 2017, 2679-2678.

5. Armstrong A.W., Harskamp C.T., Armstrong E.J.: Psoriasis and metabolic syndrome: a systematic review and meta-analysis of observational studies. J Am Acad Dermatol 2013, 68(4), 654-662.

6. Rochalni Y., Pothineni N.V., Kovelamudi S., Mehta J.L.: Metabolic syndrome: pathophysiology, management, and modulation by natural compounds. Ther Adv Cardiovasc Dis 2017, 11, 215-225.

7. Gisondi P., Fostini A.C., Fossa I., Girolomoni G., Targher G.: Psoriasis and the metabolic syndrome. Clin Dermatol 2018, 36, 21-28.

8. Miao C., Li J., Li Y., Zhang X.: Obesity and dyslipidemia in patients with psoriasis: A case-control study. Medicine (Baltimore) 2019,98 , e16323.

9. Kiluk P., Kiluk I.E., Baran A., Myśliwiec H., Flisiak I.: Występowanie zespołu metabolicznego u pacjentów z łuszczycą analiza retrospektywna 302 przypadków. Dermatol Klin 2014, 16, 57-61.

10. Azfar R.S., Gelfand J.M.: Psoriasis and metabolic disease: epidemiology and pathophysiology. Curr Opin Rheumatol 2008, $20,416-422$. 
11. Nakhwa Y.C., Rashmi R., Basavaraj K.H.: Dyslipidemia in psoriasis: a case controlled study. Int Sch Res Notices 2014, 2014, 729157.

12. Coto-Segura P., González-Lara L., Eiris N., Santos-Juanes J., Queiro R., Coto E.: Effect of the FTO rs9930506 polymorphism on obesity and the main clinical outcomes in patients with psoriasis. Br J Dermatol 2014, 171, 917-919.

13. Jin Y., Zhang F., Yang S., Kong Y., Xiao F., Hou Y., et al.: Combined effects of HLA-Cw6, body mass index and waist-hip ratio on psoriasis vulgaris in Chinese Han population. J Dermatol Sci 2008, 52, 123-129.

14. Armstrong A.W., Harskamp C.T., Armstrong E.J.: The association between psoriasis and obesity: a systematic review and meta-analysis of observational studies. Nutr Diabetes 2012, 2, e54.

15. Setty A.R., Curhan G., Choi H.K.: Obesity, waist circumference, weight change, and the risk of psoriasis in women: Nurses Health Study II. Arch Intern Med 2007, 167, 1670-1675.

16. Hogan A.E., Tobin A.M., Ahern T., Corrigan M.A., Gaoatswe G., Jackson R., et al: Glucagon-like peptide-1 (GLP-1) and the regulation of human invariant natural killer T cells: lessons from obesity, diabetes and psoriasis. Diabetologia 2011, 54, 2745-2754.

17. Boehncke W.H., Boehncke S., Tobin A.M., Kirby B.: The "psoriatic march": a concept of how severe psoriasis may drive cardiovascular comorbidity. Exp Dermatol 2011, 20, 303-307.

18. Sajja A.P., Joshi A.A., Teague H.L., Dey A.K., Mehta N.N.: Potential immunological links between psoriasis and cardiovascular disease. Front Immunol 2018, 9, 1234.

19. Gerdes S., Rostami-Yazdi M., Mrowietz U.: Adipokines and psoriasis. Exp Dermatol 2011, 20, 81-87.

20. Qureshi A.A., Choi H.K., Setty A.R., Curhan G.C.: Psoriasis and the risk of diabetes and hypertension: a prospective study of US female nurses. Arch Dermatol 2009, 145, 379-382.

21. Kim H.N., Han K., Song S.W., Lee J.H.: Hypertension and risk of psoriasis incidence: an 11-year nationwide population-based cohort study. PLoS One 2018, 13, e0202854.

22. Armstrong A.W., Harskamp C.T., Armstrong E.J.: The association between psoriasis and hypertension. J Hypertens 2013, 31, 433-443.

23. Holm J.G., Thomsen S.F.: Type 2 diabetes and psoriasis: links and risks. Psoriasis (Auckl) 2019, 9, 1-6.

24. Owczarczyk-Saczonek A., Nowicki R.: Patofizjologia związków łuszczycy z zaburzeniami metabolicznymi. Przegl Dermatol 2013, 100, 125-131.

25. Komorowska O.R., Szczerkowska-Dobosz A., Purzycka-Bohdan D., Rawicz-Zegrzda D., Dudziak M. Łuszczyca jako czynnik ryzyka rozwoju chorób serca i naczyń. Przegl Dermatol 2014, 101, 500-506.

26. Lima Ede A., Lima M.M., Marques C.D., Duarte A.L., Pita Ida R., Pita M.G.: Peroxisome proliferator-activated receptor agonists (PPARs): a promising prospect in the treatment of psoriasis and psoriatic arthritis. An Bras Dermatol 2013, 88, $1029-1035$.

27. Rhee E.J., Kim H.C., Kim J.H., Lee E.H., Kim B.J., Kim E.M., et al.: 2018 Guidelines for the management of dyslipidemia. Korean J Intern Med 2019, 34, 723-771.

28. Ahmed S.M., Clasen M.E., Donnelly J.F.: Management of dysplipidemia in adults. Am Fam Physician 1998, 57, $2192-2204$.

29. Salihbegovic E.M., Hadzigrahic N., Suljagic E., Kurtalic N., Hadzic J., Zejcirovic A., et al.: Psoriasis and dyslipidemia. Mater Sociomed 2015, 27, 15-17.

30. Pietrzak A., Chabros P., Grywalska E., Kiciński P., Pietrzak-Franciszkiewicz K., Krasowska D., et al. Serum lipid metabolism in psoriasis and psoriatic arthritis - an update. Arch Med Sci 2019, 15, 369-375.

31. Trong H.N., Tat T.N., Anh T.T.N., Uyen N.P., Van T.N., Hau K.T.: Efficacy of adding oral simvastatin to topical therapy for treatment of psoriasis: the vietnamese experience. Open Access Maced J Med Sci 2019, 7, 237-242.

32. Späh F.: Inflammation in atherosclerosis and psoriasis: common pathogenic mechanisms and the potential for an integrated treatment approach. Br J Dermatol 2008, 159, 10-17.

33. Lockshin B., Balagula Y., Merola J.F.: Interleukin 17, inflammation, and cardiovascular risk in patients with psoriasis. J Am Acad Dermatol 2018, 79, 345-352.

34. Yiu K.H., Yeung C.K., Chan H.T., Wong R.M., Tam S., Lam K.F., et al.: Increased arterial stiffness in patients with psoriasis is associated with active systemic inflammation. Br J Dermatol 2011, 164, 514-520.

35. Prussick R., Prussick L., Nussbaum D.: Nonalcoholic fatty liver disease and psoriasis: what a dermatologist needs to know. J Clin Aesthet Dermatol 2015, 8, 43-45.

36. Mantovani A., Gisondi P., Lonardo A., Targher G.: Relationship between non-alcoholic fatty liver disease and psoriasis: a novel hepato-dermal axis? Int J Mol Sci 2016, 17, 217.

37. Gisondi P., Del Giglio M., Cozzi A., Girolomoni G.: Psoriasis, the liver, and the gastrointestinal tract. Dermatol Ther 2010, 23, 155-159.

38. Reich A., Adamski Z., Chodorowska G., Kaszuba A., Krasowska D., Lesiak A., et al.: Psoriasis. Diagnostic and therapeutic recommendations of the Polish Dermatological Society. Part 2. Przegl Dermatol 2020, 107, 110-137.

39. Lee S., Koo J.: A review of acitretin, a systemic retinoid for the treatment of psoriasis. Expert Opinion Pharmacother 2005, 6, 1725-1734.

40. Ahlehoff O., Skov L., Gislason G., Gniadecki R., Iversen L., Bryld L.E., et al.: Cardiovascular outcomes and systemic anti-inflammatory drugs in patients with severe psoriasis: 5-year follow-up of a Danish nationwide cohort. J Eur Acad Dermatol Venereol 2015, 29, 1128-1134.

41. Scheinfeld, N. Adalimumab: a review of side effects 2005. Expert Opinion Drug Saf 2005, 4, 637-641.

42. Hanssen S.C.A., van der Vleuten C.J.M., van Erp P.E.J., Seyger M.M.B., van de Kerkhof P.C.M.: The effect of adalimumab on the vasculature in psoriatic skin lesions. J Dermatolog Treat 2019, 30, 221-226.

43. Caiazzo G., Fabbrocini G., Di Caprio R., Raimondo, A., Scala, E., Balato, N., et al. Psoriasis, cardiovascular events and biologics: lights and shadows. Front Immunol 2018, 9, 1668.

44. Kim G.K., Del Rosso J.Q.: Drug-provoked psoriasis: is it drug induced or drug aggravated?: understanding pathophysiology and clinical relevance. J Clin Aesthet Dermatol 2010, 3, 32-38. 
45. Debbaneh M., B.A., Jillian W. Millsop, M.S., Bhatia BK, Koo J, Liao W. Diet and psoriasis, part I: Impact of weight loss interventions. J Am Acad Dermatol 2014, 71, 133-140.

46. Naldi, L., Conti, A., Cazzaniga, S., Patrizi, A., Pazzaglia, M., Lanzoni, A.: Diet and physical exercise in psoriasis: a randomized controlled trial. Br J Dermatol 2014, 170, 634-642.

47. Solis M.Y., de Melo N.S., Macedo M.E., Carneiro F.P., Sabbag C.Y., Lancha Júnior A.H., et al.: Nutritional status and food intake of patients with systemic psoriasis and psoriatic arthritis associated. Einstein (Sao Paulo) 2012, 10, 44-52.

48. Wilson P.B., Bohjanen K.A., Ingraham S.J., Leon A.S.: Psoriasis and physical activity: a review. J Eur Acad Dermatol Venereol 2012, 26, 1345-1353.

49. Rucević I., Perl A., Barisić-Drusko V., Adam-Perl M.: The role of the low energy diet in psoriasis vulgaris treatment. Coll Antropol 2003, 27, 41-48.

50. Cybulska B., Kłosiewicz-Latoszek L., Szostak W.: Dyslipedmie. [w:] Interna Szczeklika 2017. A. Budaj (eds.). Medycyna Praktyczna, Kraków, 2017, 155-164..

51. Krahel J.A., Baran A., Kamiński T.W., Flisiak I.: Proprotein Convertase Subtilisin/Kexin Type 9, Angiopoietin-Like Protein 8, Sortilin, and Cholesteryl Ester Transfer Protein-Friends of foes for psoriatic patients at the risk of developing cardiometabolic syndrome? Int J Mol Sci 2020, 21, 3682.

52. Pfeifer EC, Saxon DR, Janson RW. Etanercept-induced hypoglycemia in a patient with psoriatic arthritis and diabetes. J Investig Med High Impact Case Rep 2017, 5, 2324709617727760.

53. Mehta N.N., Krishnamoorthy P., Yu Y., Khan O., Raper A., Van Voorhees A., et al.: The impact of psoriasis on 10-year Framingham risk. J Am Acad Dermatol 2012, 67, 796-798.

54. Elmets C.A., Leonardi C.L., Davis D.M.R., Gelfand J.M., Lichten J., Mehta N.N., et al: Joint AAD-NPF guidelines of care for the management and treatment of psoriasis with awareness and attention to comorbidities. J Am Acad Dermatol 2019, 80,4, 1073-1113.

55. Alamdari H.S., Gustafson C.J., Davis S.A., Huang W., Feldman S.R.: Psoriasis and cardiovascular screening in the United States. J Drugs Dermatol 2013, 12, e: 14-9.

56. Manalo I.F., Gilbert K.E., Wu J.J.: Survey of trends and gaps in dermatologists' cardiovascular screening practices in psoriasis patients: areas still in need of improvement. J Am Acad Dermatol 2015, 73, 872-874

57. Wójcik-Maciejewicz A., Sawińska E., Reich A.: Risk of cardiovascular diseases in psoriasis - the current state of knowledge. Przegl Dermatol 2019, 106, 495-506.

Received: 22.04 .2020

Accepted: 31.08 .2020

Otrzymano: 22.04 .2020 r.

Zaakceptowano: 31.08.2020 r.

How to cite this article

Nowowiejska J., Baran A., Flisiak I.: Psoriasis and cardiometabolic disorders. Dermatol Rev/Przegl Dermatol 2020, 107, 508-520. DOI: https://doi.org/10.5114/dr.2020.103887 